\title{
Transplante de células tronco mesenquimais pode auxiliar a regeneração periodontal
}

A regeneração parcial dos tecidos periodontais pode ser obtida por meio de uma série de técnicas, tais como a regeneração tecidual guiada e uso de fatores de crescimento polipeptídicos. Uma técnica recente, que tem sido aplicada na regeneração tecidual de diferentes tecidos e órgãos, é a colonização da área afetada por células tronco da medula óssea. Essas células podem ser obtidas com facilidade e já se demonstrou que podem se diferenciar em osteoblastos, condrócitos, adipócitos, células musculares, entre outras. Pesquisadores da Universidade de Hiroshima, no Japão, fizeram um transplante de células tronco mesenquimais da medula óssea de cães para tratar defeitos de furca de Classe III em cães, e relataram seus achados no fascículo de setembro de 2004 do Journal of Periodontology. Inicialmente, as células tronco foram aspiradas da crista ilíaca dos animais, cultivadas em meios de cultura, e armazenadas em nitrogênio líquido até o momento de seu emprego. Quando defeitos de furca de Classe III foram criados, suspensões de células tronco em diferentes concentrações foram transplantadas para o defeito, embebidas em um veículo em gel contendo colágeno do Tipo I. Os animais foram mortos, e blocos de tecido foram removidos, descalcificados e processados para microscopia de luz. Os autores quantificaram a regeneração dos tecidos periodontais e compararam a regeneração ocorrida nos cães que receberam diferentes concentrações de células tronco com aquela apresentada por animais controle, que não receberam o transplante celular. Os resultados desse trabalho mostraram que as células tronco, nas condições do estudo, aumentaram à quantidade de regeneração periodontal. $\mathrm{O}$ aprimoramento dessa técnica, em conjunto com a facilidade de obtenção das células tronco, pode trazer novas perspectivas para o tratamento de pacientes com periodonto reduzido. Isso também poderá aumentar o potencial das correções ortodônticas.

KAWAGUCHI, H., et al. Enhancement of Periodontal Tissue Regeneration by Transplantation of Bone Marrow Mesenchymal Stem Cells. J Periodontol, Chicago, v. 75, n. 9, p. 1281-1287, sept. 2004

\section{Descoberto um novo mecanismo de defesa celular contra infecções bacterianas}

A autofagia para degradação de componentes citoplasmáticos em células eucarióticas é um importante processo da vida celular. Ela ocorre pelo englobamento de parte do citoplasma por uma membrana e o conjunto recebe o nome de autofagossomo. Posteriormente à sua formação, o conteúdo do autofagossomo é degradado através da fusão deste com lisossomos, que possuem enzimas específicas para esse fim. Um grupo de pesquisadores japoneses se debruçou sobre a possível participação da autofagia no processo de defesa celular de células não envolvidas diretamente no processo imunológico. Esse grupo, formado em sua maior parte por dentistas, relatou seus achados no fascículo de 5 de novembro de 2004 da revista Science. Eles acompanharam o destino do Streptococcus pyogenes dentro das células avaliadas. Essa bactéria é também denominada Streptococcus do Grupo A (SGA), sendo o agente etiológico de um grande número de doenças humanas. Os autores puderam observar, através de técnicas imunohistoquímicas, que os SGA, inicialmente, eram incluídos em autofagossomos.
Testes adicionais demonstraram que a maquinaria celular dessas estruturas foi capaz de matar os SGA e conter a expansão da infecção, todavia, a fusão dessas vesículas com lisossomos foi importante para matar as bactérias de uma forma eficaz. Outros ensaios demonstraram que decorridas 24 horas da infecção com SGA, aproximadamente $50 \%$ das células realizaram apoptose (morte programada) e esses resultados sugerem que a morte das bactérias SGA pelo mecanismo de autofagia não é capaz de proteger as células. Todavia, é possível que esse mecanismo contribua de forma importante para diminuir a virulência dos SGA, porque a morte das bactérias dentro das células reduz a quantidade de SGA no meio extracelular, atenuando a infecção. Essa descoberta poderá trazer novos entendimentos a respeito do mecanismo de defesa do organismo contra infecções, como o que ocorre na doença periodontal inflamatória crônica.

NAKAGAWA, I., et al. Autophagy Defends Cells Against Invading Group A Streptococcus. Science, v. 306, n. 5698, p. 1037-1040, nov. 2004.

Essa seção é realizada pelo Dr. Jorge Faber, Doutor em Biologia Animal, Laboratório de Microscopia Eletrônica - UnB e Mestre em Ortodontia - UFRJ (jorgefaber@terra.com.br). Envie suas sugestões e opiniões para o e-mail dental@dentalpress.com.br. 